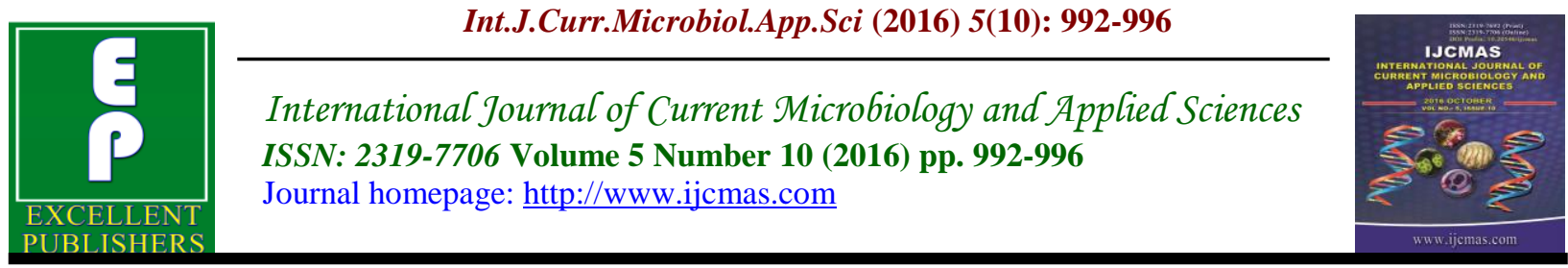

Original Research Article

http://dx.doi.org/10.20546/ijcmas.2016.510.105

\title{
Seroprevalence of Anti HCV Antibodies in a Tertiary Care Hospital in Tumkuru, India
}

\author{
T.V. Parimala* \\ Department of Microbiology, Shridevi Institute of Medical Sciences and \\ Research Hospital, NH4, Sira road, Tumkuru, India \\ *Corresponding author
}

\begin{abstract}
A B S T R A C T
Keywords

Hepatitis,

$\mathrm{HCV}$,

Seroprevalence, anti $\mathrm{HCV}$

antibody, Tertiary care hospital.

\section{Article Info}

Accepted:

28 September 2016

Available Online:

10 October 2016

Hepatitis $\mathrm{C}$ virus is a hepatotrophic virus and is the leading cause of cirrhosis and hepatocellular carcinoma. This retrospective study was conducted to determine the seroprevalence of anti HCV antibodies in a tertiary care hospital, Tumkuru, India. A total of 2093 serum samples were tested for detection of anti HCV antibodies using commercially available kit during a period from April 2015-March 2016.Anti HCV reactivity was highest in the age group 51-60(45.45\%) and more significant in females (54.54\%). Most cases were detected during routine screening of patients before surgery. The seroprevalence rate was 0.52 in the present study. Stringent measures like screening of blood samples for HCV infection need to be adapted to prevent transmission of Hepatitis C.
\end{abstract}

\section{Introduction}

Hepatitis is a disorder involving the inflammation of liver that may progress to hepatic cell necrosis leading to fibrosis. This in turn may result into serious clinical, biochemical and histological changes. Also viral hepatitis is a cause of considerable illness and death in human population both from acute infection and chronic sequelae (Prakash et al., 2011). Hepatitis $\mathrm{C}$ virus is one of the etiological agent of viral hepatitis. Hepatitis $\mathrm{C}$ is an emerging infectious disease all over the world especially in the developing countries. With approximately 170 million people worldwide estimated to be infected with $\mathrm{HCV}$, a figure that is 4 times the HIV infection status (Naik et al., 2012). HCV is a single stranded positive sense RNA virus, 9.6kb in length \& belongs to family Flaviviridae and genus Hepacivirus. There are about 180 million carriers \& approximately 4 million people annually are newly infected (Soin et al., 2015).

Hepatitis C virus impacts global health system to a large extent being responsible for significant morbidity and mortality as $\mathrm{HCV}$ can lead to chronic liver disease 
causing cirrhosis, hepatocellular carcinoma and end stage liver disease among 5-20\% of infected patients (Chakraborthy et al., 2015). The present study was conducted to determine the seroprevalence of anti HCV antibody among patients in Shridevi Institue of Medical sciences and Research Hospital, Tumkuru, India.

\section{Materials and Methods}

This is a retrospective study. This study was conducted in the serology lab,department of microbiology, Shridevi Institue of Medical Sciences and Research Hospital which is a tertiary care hospital located at Tumkuru, India. A total of 2093 patients who were admitted or attending OPD in our hospital were tested for Hepatitis $\mathrm{C}$ infection during the period from April 2015 to March 2016.

All serum samples were tested for antibodies to HCV using $4^{\text {th }}$ generation HCV TRIDOT (Diagnostic enterprises), utilizes a unique combination of modified $\mathrm{HCV}$ antigens from the putative core, NS3, NS4 \& NS5 regions of the virus to selectively identify all subtypes of Hepatitis C virus with $100 \%$ specificity and $100 \%$ sensitivity. The kits were used in accordance with the manufacturer instructions. Data were analyzed with Microsoft excel.

\section{Results and Discussion}

A total of 2093 serum samples were tested for detection of anti HCV antibodies. Of the 2093 serum samples, 11 were reactive for anti HCV antibodies. The prevalence of anti $\mathrm{HCV}$ antibody was $0.52 \%$.The highest prevalence of anti $\mathrm{HCV}$ antibodies was observed in the age group of 51-60yrs $05(45.45 \%)$ followed by $31-40$ age group 03 $(27.27 \%)$ and then in the age group 11-30yrs $1(9.09 \%)$ (Table 1). Out of the $11 \mathrm{HCV}$ reactive patients $05(45.45 \%)$ were males and $06(54.54 \%)$ were females (Table 2). Maximum anti HCV reactivity was observed in surgery and allied department 07 $(63.63 \%)$ and then in Medicine and allied department 2(18.18\%)(Table 3)

Hepatitis C virus (HCV), a global health problem and is also prevalent in India (Jindal et al., 2006). The worrying aspect of acute hepatitis $\mathrm{C}$ infection is that spontaneous viral clearance is unusual with nearly $54-86 \%$ of the infected individuals progressing to chronic hepatitis (Reker et al., 2014).

Increasing trend of anti $\mathrm{HCV}$ serpositivity with advancing age was observed in the present study. The highest prevalence of anti HCV antibodies was observed in the age group of 51- 60yrs $(45.45 \%)$. The late positivity of anti HCV may be due to exposure to its risk factor at later Stage (Khatak et al., 2002). Several studies reported seroprevalence of $\mathrm{HCV}$ was more in male patients than in females patients (Soin D et al., 2015). But in this study, was more in female patients $(54.54 \%)$.

The transmission of HCV occurs primarily through exposure to infected blood which may be due to blood transfusion, organ transplantation, intravenous drug use, body piercing, tattoo in, haemodialysis and occupational exposure among healthcare worker, therapeutic injections, major/minor surgeries, dental treatment, shaving at barbar shop, unprotected sexual contact and vertical transmission(Makroo et al., 2013) (Soin et al., 2015). Among $11 \mathrm{HCV}$ reactive cases, one $\mathrm{HCV}$ reactive patient had a history of blood transfusion and other had cirrhosis. Two HCV reactive patients were admitted for viral fever. 
Table.1 Age Distribution of Hepatitis C infection Among Patients in a Tertiary Care Hospital

\begin{tabular}{|c|c|c|c|c|}
\hline Age(Yrs) & $\begin{array}{l}\text { No. of Pts } \\
\text { Screened }\end{array}$ & $\%$ & $\begin{array}{l}\text { No. of HCV } \\
\text { Reactive Patients }\end{array}$ & $\%$ \\
\hline $1-10$ & 111 & 5.30 & 0 & 0 \\
\hline $11-20$ & 155 & 7.40 & 1 & 9.09 \\
\hline $21-30$ & 418 & 19.97 & 1 & 9.09 \\
\hline $31-40$ & 403 & 19.25 & 3 & 27.27 \\
\hline $41-50$ & 351 & 16.77 & 0 & 0 \\
\hline $51-60$ & 286 & 13.66 & 5 & 45.45 \\
\hline$>60$ & 369 & 17.63 & 1 & 09.09 \\
\hline Total & 2093 & & 11 & \\
\hline
\end{tabular}

Table.2 Sex Distribution of Hepatitis C infection Among Patients in a Tertiary Care Hospital

\begin{tabular}{|l|l|c|c|c|}
\hline Sex & $\begin{array}{l}\text { No. of Pts } \\
\text { Screened }\end{array}$ & $\%$ & $\begin{array}{l}\text { No. of HCV } \\
\text { Reactive Patients }\end{array}$ & $\%$ \\
\hline Male & 1312 & 62.68 & 05 & 45.45 \\
\hline Female & 781 & 37.31 & 06 & 54.54 \\
\hline Total & 2093 & & 11 & \\
\hline
\end{tabular}

Table.3 Prevalence of Anti HCV Antibotias Among Different Department in a Tertiary Care Hospital

\begin{tabular}{|l|l|l|l|l|}
\hline \multicolumn{1}{|c|}{ Department } & $\begin{array}{l}\text { No. of Pts } \\
\text { Screened }\end{array}$ & & $\begin{array}{l}\text { No. of HCV } \\
\text { Reactive Patients }\end{array}$ & $\%$ \\
\hline Medicine \& Allied & 300 & 14.33 & 02 & 18.18 \\
\hline Surgery \& Allied & 1030 & 49.21 & 07 & 63.63 \\
\hline OBG & 126 & 6.02 & 0 & 0 \\
\hline Ortho & 495 & 23.65 & 01 & 9.09 \\
\hline Causality & 68 & 3.24 & 01 & 9.09 \\
\hline Pediatrics & 64 & 3.05 & 0 & 0 \\
\hline Mental Health & 10 & 0.47 & 0 & 0 \\
\hline
\end{tabular}

Rest of the HCV reactive cases were detected during preoperative screening of patients. Hence our study recommends screening of patients for $\mathrm{HCV}$ infection before surgery to reduce the risk of transmission. Global and region specific estimates of $\mathrm{HCV}$ prevalence vary greatly (Reker et al., 2014).

About 0.04 to $26 \%$ of apparently healthy population in different countries of the world is suffering from chronic HCV infection. Prevalence $2.5 \%$ in SEAR countries (Prakash et al., 2011). A recent study in rural Cambodia reports high prevalence rate of $\mathrm{HCV}$ antibodies (14.7\%) (Viet et al., 2012). Similar studies from other countries demonstrated that prevalence of HCV was $18.2 \%$ Korea between 2005 and 2006. Prevalence of anti HCV antibody positivity in Pakistan was found $4.8 \%$ in 11 year surveillance study performed in 47043 patients. In Turkey, prevalence of anti HCV antibody positivity is $1-2.4 \%$ (Turangolu et al., 2013). 
The seroprevalence of $\mathrm{HCV}$ in the general population has been studied extensively and reports from different parts of India show the seroprevalence of $\mathrm{HCV}$ infection to be as varied as $0.3-11.3 \%$ (Jindal et al., 2006). In India prevalence studies done in Arunachal Pradesh showed a higher rate of $7.89 \%$ as compared to Maharastra $(0.09 \%)$, Andrapradesh (1.4\%) and West Bengal (0.71\%) (Naik et al., 2012)In a recent study done in Hisar, Haryana the seroprevalence of anti HCV antibody was calculated to be $1 \%$.A study done in Orissa reported anti HCV seroprevalence to be $1.98 \%$ (Makroo et al., 2013). In the present study, the overall prevalence of anti HCV antibody in Shridevi Institute of Medical Sciences and Research Hospital, Tumkuru was found to be $0.52 \%$.

Our study has certain limitations. First, HCV infection was based on detection of by antibodies rather than detection of $\mathrm{HCV}$ RNA. The antibody may never become detectable in $5-10 \%$ patients with acute hepatitis $\mathrm{C}$ and levels of anti HCV may become undetectable often recovery (albeit rare) from acute hepatitis $C$. In patients with chronic hepatitis $\mathrm{C}$, anti $\mathrm{HCV}$ is detectable in $95 \%$ of cases (Chakraborthy et al., 2015). Second, this study was conducted in only one hospital, so cannot be directly generalized to the entire population.

\section{Acknowledgement}

I am thankful to entire technical staff of the department of Microbiology, Shridevi Institute of Medical Sciences and Research Hospital, Tumkuru, India.

\section{References}

Chakraborty, A., Pramanik, SB., Roy, DS., Sarkar, S., Chakraborty, M., and Nandi, A. 2015. Int. J. Curr. Microbiol. App. Sci., 4(3): 115-123.

Jindal, N., Jindal, M., Jilani, N., and Kar, P.
2006. Seroprevalence of hepatitis C virus $(\mathrm{HCV})$ in health care workers of a tertiary care centre in New Delhi. Indian J. Med. Res., 123: 179-180.

Khattak, M.F., Salamat, N., Bhatti, F.A., and Quershi, T.Z. 2002. Seroprevalence of Hepatitis B, C and HIV in Blood Donors in Northern Pakistan. J. Pak. Med. Assoc., Online.

Makroo, R.N., Walia, R.S., Chowdry, M., Bhatia, Aakanksha., Hegde, V., and Rosamma, N.L. 2013. Seroprevalence of anti-HCV antibodies among blood donors of north India. Indian $\mathrm{J}$ Med Res., 138: 125-128.

Naik, S.A., Banashankari, G.S., Beena, Gayathri devi, D.R., Sreeja. S. 2012. Prevalence of Hepatitis Cinfection in a Tertiary care Hospital in South India. National J. Lab. Med., 1(1): 20-22.

Norouzian, H., Gholami, M., Shakib, P., Gholam, Diali, H.G., and Rezvani, A. 2016. Prevalence of HCV infections and co infection with HBV and associated Risk factors among addicts in Drug Treat Centers, Lorestan Provinence, Iran. International journal of High risk Behaviours and Addiction. Online.

Prakash, G., Gandha Kapil, M., and Goswami, Y.S. 2011. Study on Prevalence of Hepatitis $\mathrm{C}$ infection in healthy and high risk groups. 2(4):1517.

Reker, C., and Islam, K.M. 2014. Risk factors associated with high prevalence rates of hepatitis $\mathrm{C}$ infection in Egypt. Int. J. Infect. Dis., 25: 104-106.

Soin, D., Grover, P., Malhotra, R. 2015. Hepatitis $\mathrm{C}$ virus infection in dialysis patients: A retrospective study from a Tertiary care Hospital. Int. J. Res. Dev. Pharm. L. Sci., 4(3): 1529-1532.

Turhanoglu, M., Onur, A., Bilman, F.B., Ayadin, Z., and Aktar, G.S. 2013. 
Eight -year seroprevalence of HBV, $\mathrm{HCV}$ and HIV in Diyarbakir Training and Research Hospital. Int. J. Med. Sci., 10(11): 1595-1601.

Viet, L., Lan, N.T., Ty, P.X., Bjorkvoll, B.,
Hoel, H., Guttenberg, T. et al. 2012. Prevalence of hepatitis B \& hepatitis C virus infections in Potential blood donors in rural Vietnam. Indian $J$. Med. Res., 136: 74-81.

\section{How to cite this article:}

Parimala, T.V., 2016. Seroprevalence of Anti HCV Antibodies in a Tertiary Care Hospital in Tumkuru, India. Int.J.Curr.Microbiol.App.Sci. 5(10): 992-996. doi: http://dx.doi.org/10.20546/ijcmas.2016.510.105 